\title{
Seasonal temperature variations controlling cave ventilation processes in Cueva Larga, Puerto Rico
}

\author{
Rolf Vieten $^{1 *}$, Amos Winter ${ }^{1,2}$, Sophie F. Warken ${ }^{3,4}$, Andrea Schröder-Ritzrau ${ }^{4}$, \\ Thomas E. Miller ${ }^{5}$, and Denis Scholz ${ }^{3}$ \\ ${ }^{1}$ Department of Marine Science, University of Puerto Rico, Mayagüez, PR 00680, USA \\ ${ }^{2}$ Department of Earth and Environmental Systems, Indiana State University, Terre Haute, IN 47809, USA \\ ${ }^{3}$ Institute of Geosciences, Johannes Gutenberg University Mainz, 55128 Mainz, Germany \\ ${ }^{4}$ Institute of Environmental Physics, Ruprecht-Karls-University Heidelberg, 69120 Heidelberg, Germany \\ ${ }^{5}$ Department of Geology, University of Puerto Rico, Mayagüez, PR 00681, USA
}

Abstract: $\quad$ Two years of cave monitoring investigate ventilation processes in Cueva Larga, a tropical cave in Puerto Rico. The cave is $1,440 \mathrm{~m}$ long with a large main passage (about $120,000 \mathrm{~m}^{3}$ ). Cave air $\mathrm{pCO}_{2}$ in the main passage varies seasonally, between $600 \mathrm{ppm}$ in winter and 1,800 ppm in summer. The seasonal variability in cave $\mathrm{pCO}_{2}$ permits the estimation of a cave air exchange time of $36 \pm 5$ days and a winter ventilation rate of $3,300 \pm 1,000 \mathrm{~m}^{3} / \mathrm{day}$ for the main cave passage. Calculations of virtual temperature and differences between cave and surface temperature indicate that the seasonal temperature cycle is the main driver of the alternation between a well-ventilated winter mode and a near-stagnant summer mode. The winter mode is characterized by a positive buoyancy contrast at night leading to maximal cave ventilation, while cave ventilation is at a minimum during summer. Between winter and summer, a transitional mode of partial cave ventilation is observed. On shorter time scales (diurnal to weekly), cave $\mathrm{pCO}_{2}$ is also influenced by atmospheric pressure but this variation is one order of magnitude lower than the seasonal $\mathrm{pCO}_{2}$ change. The cave morphology of Cueva Larga including its large volume, tubular shape and the obstructed cave entrance geometry are important boundary conditions for the observed ventilation patterns. Our findings emphasize that cave systems with varying morphology have to be studied individually in order to correctly describe ventilation processes.

Keywords: environmental monitoring, cave ventilation, carbon dioxide, virtual temperature, air exchange time Received 15 February 2016; Revised 13 October 2016; Accepted 13 October 2016

Citation: $\quad$ Vieten R., Winter A., Warken S.F., Schröder-Ritzrau A., Miller T.E. and Scholz D., 2016. Seasonal temperature variations controlling cave ventilation processes in Cueva Larga, Puerto Rico. International Journal of Speleology, 45 (3), 259-273. Tampa, FL (USA) ISSN 0392-6672 http://dx.doi.org/10.5038/1827-806X.45.3.1983

\section{INTRODUCTION}

Monitoring of cave environments is necessary to improve understanding of speleothem growth processes (Fairchild et al., 2007; Fairchild \& Baker, 2012), improve paleo-climatic reconstructions (James et al., 2015), and enhanced archeological site conservation (Fernández et al., 1986). Deep cave environments exhibit near-constant temperatures over annual and diurnal cycles and relative humidity values close to $100 \%$ (Lachniet, 2009; Fairchild \& Baker, 2012). Speleothems growing in these conditions make ideal climate archives because kinetic isotope effects and annual variations in the temperature dependent fractionation factor are considered to be extremely low (Kim \& O’Neil, 1997; Mickler et al., 2006; Mattey et al., 2010; Deininger et al., 2012).
Variations in $\mathrm{CO}_{2}$ partial pressure $\left(p \mathrm{CO}_{2}\right)$ of the cave atmosphere (Boch \& Spötl, 2008; Baker et al., 2014) can affect commonly used paleo-climatic proxies of speleothems e.g., growth rates, stable isotope ratios and trace element ratios (Dreybrodt, 1999; Wong et al., 2011; Deininger et al., 2012; Breitenbach et al., 2015). Thus, it is valuable to investigate cave ventilation patterns prior to analytical work and speleothem paleoclimate interpretation (James et al., 2015). This study helps to improve the paleoclimate interpretation of tropical speleothems by investigating the connection between atmospheric changes outside the cave and the cave interior.

Cave air ventilation processes are affected by regional differences, such as latitude (James et al., 2015) and altitude (Mattey et al., 2016). In addition, cave morphologies interact in a complex manner with 
physical drivers such as variations in atmospheric temperature, air pressure and wind flow (Breitenbach et al., 2015; Mattey et al., 2016). On short time scales from hours to a few days local changes in atmospheric air pressure (e.g., during tropical low pressure systems, or via changes of wind speed and/ or direction at the cave entrances) are known to have an effect on cave ventilation (Baldini et al., 2006; Cowan et al., 2013; Breitenbach et al., 2015; Ridley et al., 2015; Mattey et al., 2016). During the passing of low pressure systems cave air expands and leaves the cave, when normal pressure conditions are reached again atmospheric air is forced into the cave. Wind field changes are linked to cave air movements via the Venturi effect causing underground pressure changes (Kowalczk \& Froelich, 2010; Breecker et al., 2012). We discuss changes in the temperature difference (dT) between the temperature inside and outside the cave and compare $d T$ to virtual temperature $\left(T_{v}\right)$ which combines the effects of elevated relative humidity and $\mathrm{pCO}_{2}$ levels to air buoyancy (Sánchez-Cañete et al., 2013). Cave monitoring took place over two years at Cueva Larga, including atmospheric $\mathrm{pCO}_{2}$, temperature $(T)$ and relative humidity $(R H)$ both inside and outside the cave. The monthly observations detect a seasonal cycle in $\mathrm{pCO}_{2}$ which allows us to estimate cave ventilation rates and to calculate $d T$ and $T_{v}$.

\section{SITE DESCRIPTION}

Cueva Larga (CL; Fig. 1), is located in an area characterized by sinkholes and mogotes $350 \mathrm{~m}$ above mean sea level (amsl) in the north central karst region of Puerto Rico in the northeastern Caribbean (N 18 $19^{\prime}$ W $\left.66^{\circ} 48^{\prime}\right)$. The area above the cave is covered by thick tropical forest with thin soil cover that is nearly absent on the higher elevated and exposed locations. The cave is dominantly a vadose cave with some phreatic features. It is located in the massive dense Oligocene Lares Limestone (Giusti, 1978; Monroe, 1980). The entrance of $C L$ is located along an inclined surface belonging to a sinkhole at the lower edge of a small hill. $C L$ has a horizontal extension of about $1,440 \mathrm{~m}$ from west to east (Miller, 2010) and a single entrance which is formed like a narrow vertical pit whereas the main passage has a tubular morphology with ceiling heights of up to $30 \mathrm{~m}$. The entrance area and the main chamber are separated by two U-shaped obstacles along the cave ceiling and one depression on the cave floor (Fig. 1B). The cave ends in the Collapse Room, a chamber where the roof has collapsed. It is separated from the main chamber by a rise in the cave passage floor. The Collapse Room is subdivided in a small lower level passage and a large upper level passage which reconnect at the end of the cave (Fig. 1 insert 3). Due to the remote location recreational cave visits are limited and therefore $C L$ is well suited for studying natural cave ventilation processes.

\section{METHODS}

\section{Weather observation}

A Vaisala WXT 520 weather sensor connected to a Campbell Scientific 200 data logger was placed in November 2012 on top of a mogote, directly over $C L$, at a height of $405 \mathrm{~m}$ amsl. Vegetation surrounding the

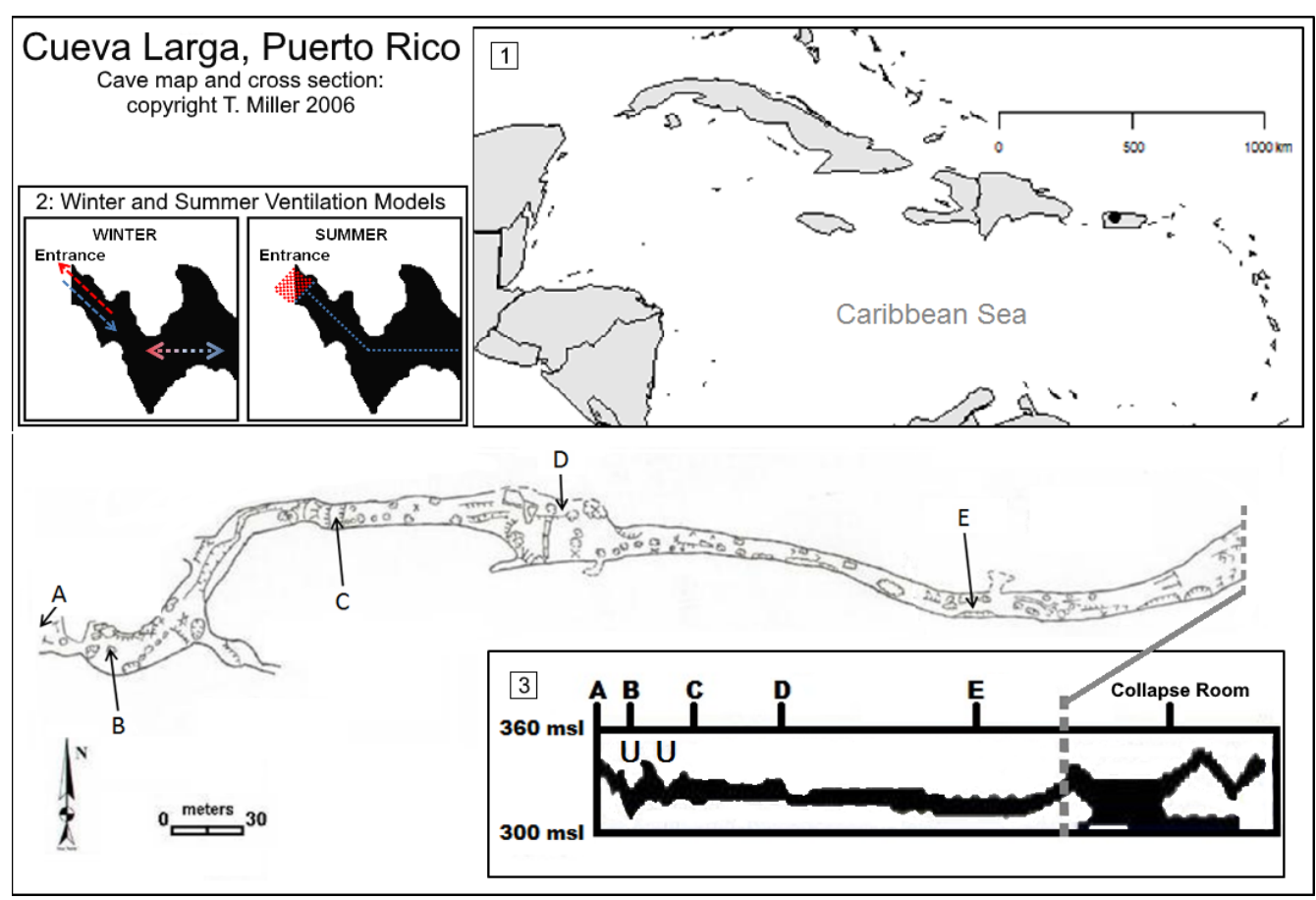

Fig. 1. Map of Cueva Larga (CL) showing the monitored sites A, B, C, D, and E. The map (Miller, 2010) shows the main passage up to the entrance to the Collapsed Room at the end of the cave. Insert 1: Map of north eastern Caribbean with the location of $C L$; Insert 2: Vertical profile of the entrance. Arrows indicate the ventilation during the winter mode (left). Blue arrows represent the cold outside air moving inside $C L$ and replacing the warmer, more buoyant cave air (red arrows). The stagnant summer mode (right) is represented by colder cave air (blue line) remaining below warmer outside air (red); Insert 3: Vertical profile of the whole cave also published in Miller (2010). The letter "U" marks the horizontal location of two "U" shaped obstacles along the cave ceiling. The vertical grey dotted line marks the location of the cut in the map. 
weather station was removed to ensure accurate readings and the direct vicinity was cleared of overgrown vegetation during each site visit. The station recorded weather data every 10 minutes: air temperature $T$ with an accuracy of $\pm 0.3^{\circ} \mathrm{C}$ at $20^{\circ} \mathrm{C}$, relative humidity ( $\pm 3 \%$ between 0 and $90 \% R H$, and $\pm 5 \%$ above $90 \% R H$ ) and barometric pressure $\mathrm{P}( \pm 0.5 \mathrm{hPa})$. Due to a system malfunction, no data was recorded from middle of June to the middle of October 2013, for 28 days between December 2013 and January 2014 and starting in November 2014 the daily records presented many missing data points. The gaps in temperature could be bridged with data from the nearby Arecibo Observatory (AO) downloaded on 12 August 2015 from the data-query tool xmACIS (http://xmacis. rcc-acis.org/). The $A O$ is located at $323 \mathrm{~m}$ amsl (82 $\mathrm{m}$ lower than the weather sensor at $C L$ ) about $10 \mathrm{~km}$ north of the cave site. By comparing daily means (Fig. 2) when both stations recorded data simultaneously (546 days) it was determined that the temperature at $A O$ is on average $1.4 \pm 1.3^{\circ} \mathrm{C}$ higher than at the $C L$ weather station. Fig. $2 \mathrm{~A}$ shows the deviation (AO-CL) of daily average temperature $(\Delta \mathrm{T})$ between the two weather stations. There is large scatter $\left(\Delta \mathrm{T}_{\min }=\right.$ $-4.8^{\circ} \mathrm{C}$ to $\Delta \mathrm{T}_{\max }=+6.2^{\circ} \mathrm{C}$ ) and most of the time $\Delta \mathrm{T}$ is positive $(87 \%)$. Assuming an altitudinal temperature decrease of about $6.5^{\circ} \mathrm{C} / 1,000 \mathrm{~m}$ (Jacobson, 2005), the lower elevation of $A O$ explains about $0.5^{\circ} \mathrm{C}$ of the difference, different initial calibrations of their respective temperature sensors and local effects (e.g., vegetation, difference in duration of daily insolation) are probable reasons for the higher value of mean $\Delta \mathrm{T}$ at $A O$. The $A O$ meteorological data was adjusted by subtracting the mean difference between the two stations.

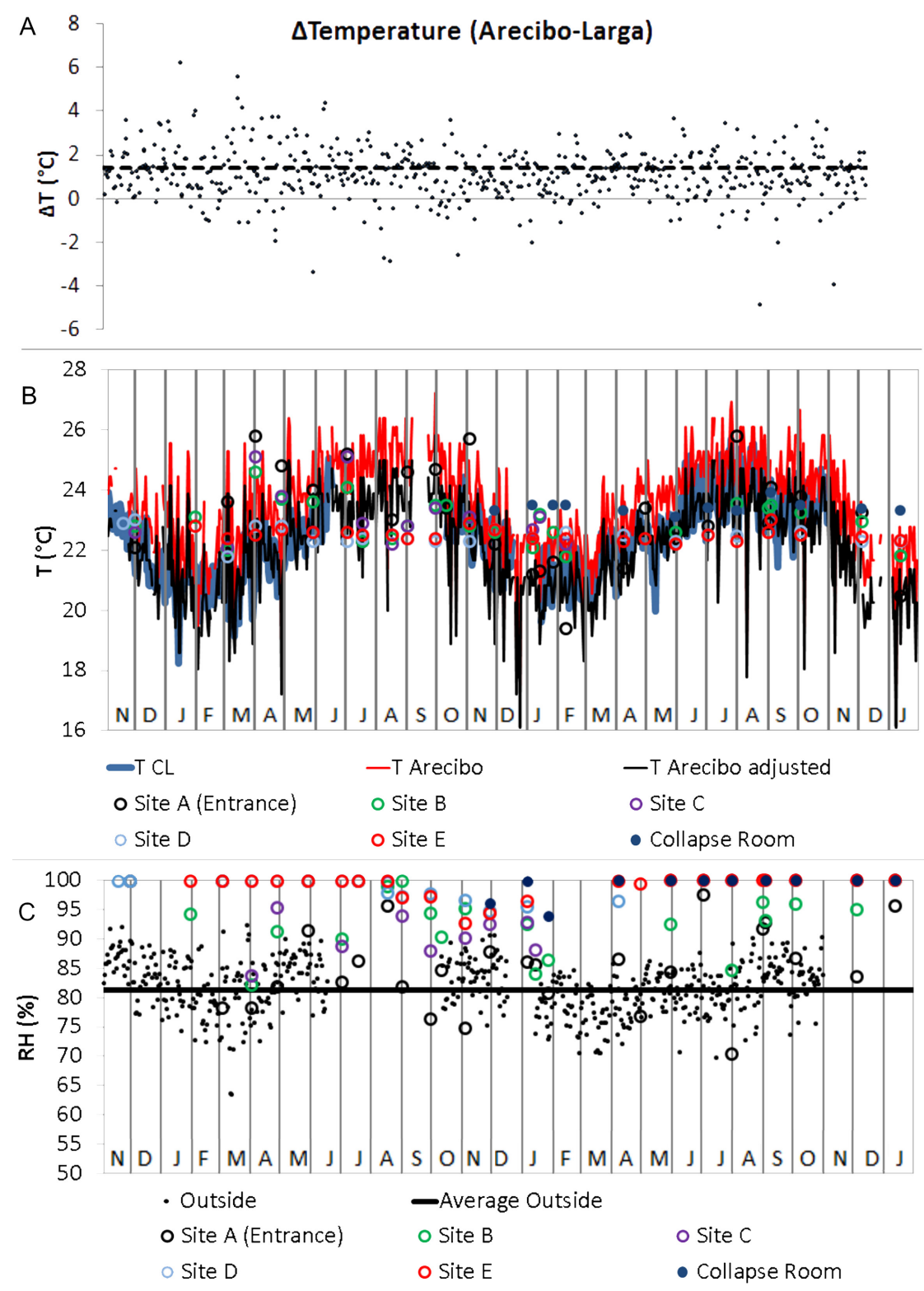

Fig. 2. Top (A) shows the difference between daily average temperatures measured at the Arecibo weather station $(A O)$ and the Cueva Larga $(C L)$ weather station. Measurements of both stations were available for 546 days. The average temperature at the $A O$ station is $1.4 \pm 1.3^{\circ} \mathrm{C}$ (black line) higher than the $C L$ weather station. Middle (B) shows the daily average $T$ at $C L$ (blue line), the daily average temperatures at $A O$ (red line), the adjusted daily average temperatures (black line) which were used to fill in the days with missing data at the $C L$ site and the temperature measurements inside $C L$ (circles). Bottom (C) shows the average daily $R H$ values for the $C L$ weather station site and the mean $R H$ value of $82 \pm 5 \%$ which was used to fill the gaps in the weather station measurements. Also shown are the $\mathrm{RH}$ measurements inside $\mathrm{CL}$ (circles). Letters in B and $\mathrm{C}$ indicate the month of the year and the vertical numbers are the calendar year.

\section{Cave monitoring}

Five cave monitoring sites inside $C L$ were visited at near monthly intervals (Fig. 1). Site A is located in the entrance of $C L(0 \mathrm{~m}$ to cave entrance) below a caveceiling-overhang and a height of $60 \mathrm{~cm}$ to the floor, sites $\mathrm{B}, \mathrm{C}, \mathrm{D}$ and $\mathrm{E}$ are inside $\mathrm{CL}$ with a distances to the cave entrance of about $50 \mathrm{~m}, 160 \mathrm{~m}, 250 \mathrm{~m}$, and $425 \mathrm{~m}$, respectively. The height above the cave floor varied among sites between 0.6 to $1.5 \mathrm{~m}$ (site B- $1.5 \mathrm{~m}$, C-1.3 m, D-0.8 m and E-0.6 m). The sites are located near the lowest part of the main cave passage except site $\mathrm{D}$ which is located at a climb along the cave wall with a distance of about $10 \mathrm{~m}$ to the floor of the main cave passage. Air pressure measurements during 5 individual field trips show that the absolute vertical height of each station does not exceed a difference of more than $12 \mathrm{~m}$ to the cave entrance. The individual measurements inside $C L$ were taken at the same location during each visit.

Cave parameters $\left(p \mathrm{CO}_{2}, T\right.$ and $\left.\mathrm{RH}\right)$ were measured at each site during each monthly cave visit. An Amprobe $\mathrm{CO}_{2}-100$ handheld carbon dioxide meter (accuracy of $\pm\left(30 \mathrm{ppm}+5 \%\right.$ of reading) for $\mathrm{pCO}_{2}$ between 0 and $5,000 \mathrm{ppm} ; \pm 0.6^{\circ} \mathrm{C}$ for $T$ and $\pm 5 \%$ for $R H$ above $90 \%$ ) was employed from January 2013 to July 2013, while from July 2013 to January 2015 we used a handheld Vaisala GM 70 with a 2,000 ppm $\mathrm{CO}_{2}$ probe (accuracy of \pm (30 ppm $+2 \%$ of reading) for $\mathrm{pCO}_{2}$ between 0 and 2,000 ppm) and a HM70 humidity and temperature probe (accuracy of $\pm 0.2^{\circ} \mathrm{C}$ for $T$ and $\pm 1.7 \%$ for $R H$ above 90\%). During two cave visits both devices collected data at the same time. The measurement 
results of both devices were in agreement with each other considering their accuracy ranges.

To detect daily $\mathrm{pCO}_{2}$ variability in the cave a $\mathrm{CM}$ 0018 data logger from $\mathrm{CO}_{2}$ Meter Inc. (accuracy of $\pm\left(30 \mathrm{ppm}+2 \%\right.$ of reading) for $p \mathrm{CO}_{2}$ and $0.4^{\circ} \mathrm{C}$ for $T)$ was placed at site $\mathrm{E}$ from 4 November 2013 to 29 November 2013 and recorded the $\mathrm{pCO}_{2}$ and $T$ value in hourly intervals. The data logger was kept in a breathable nylon bag together with a moisture absorber to prevent condensation inside the data logger.

\section{Virtual temperature calculation}

Virtual temperature $\left(T_{v}\right)$ is the temperature that dry air must reach to have the same density as moist air (Sánchez-Cañete et al., 2013). Thus, $T_{v}$ is used to determine buoyancy contrasts between two air masses with different humidity contents. The air mass with the higher $T_{v}$ has higher buoyancy. Kowalski and Sánchez-Cañete (2010; Equation 1) expanded the definition of $T_{v}$ by including the effect of high $\mathrm{CO}_{2}$ values. This is important in cave environments, where $\mathrm{CO}_{2}$ values are up to several orders of magnitudes higher than in the atmosphere (Kowalski \& SánchezCañete, 2010; Sánchez-Cañete et al., 2013).

$$
T_{v}=T *\left(1+0.6079 r_{v}-0.3419 r_{c}\right)
$$

where: $T=$ temperature in degrees Celsius, $r_{v}=$ water vapor mixing ratio, and $r_{c}=$ carbon dioxide mixing ratio.

We calculated $T_{v}$ outside and inside the cave to investigate buoyancy differences between cave and outside atmosphere using the excel template provided by Sánchez-Cañete et al. (2013). Required input parameters were $\mathrm{RH}, p \mathrm{CO}_{2}$ and $T$. For the cave air $T_{v}$ calculation $R H$ was set to $100 \%$ as suggested by Sánchez-Cañete et al. (2013) and indicated by the field observations (Fig. 2C). Choosing any $\mathrm{RH}$ value above $90 \%$ changes $T_{v}$ by only up to $0.7 \%$ resulting in a negligible change on the calculated outcome of $T_{v}$ inside the cave. The range of $R H$ at the weather station has a small influence on the $T_{v}$ calculation as $T_{v}$ changes by less than $3 \%$ when the maximum and minimum $R H$ values are used.

The annual cycle in outside air $T_{v}$ was calculated using the $C L$ weather station daily average $T$ and $R H$. No $R H$ data was available from the $A O$ weather station to fill the gaps of the $C L$ station. Instead we used the average daily $R H$ value of $82 \pm 5 \%$ (SD) from the $C L$ weather station data. This is reasonable because the data do not show a seasonal cycle (Fig. $2 \mathrm{C})$. We used a value of $400 \mathrm{ppm} \mathrm{pCO}_{2}$ to calculate outside $T_{v}$ because our measurements at the weather station above the forest agree with $400 \mathrm{ppm}$ which is within the accuracy range of the device and this is also the global atmospheric value (Tans \& Keeling, 2014). More precise $\mathrm{pCO}_{2}$ measurements could allow for the detection of a seasonal $\mathrm{pCO}_{2}$ cycle, for example a seasonal variation of $8 \mathrm{ppm}$ is observed at the Mauna Loa observatory $(2013 / 14)$. This seasonal $\mathrm{pCO}_{2}$ variation is negligible in the outside $T_{v}$ calculation because a $p \mathrm{CO}_{2}$ change of $8 \mathrm{ppm}$ causes a variation of $0.005 \%$ in outside $T_{v}$. To calculate diurnal outside $T_{v}$ variations, we used the 10 minute data recorded at the $C L$ weather station for each day that the cave was visited. At cave site $\mathrm{E}, T_{v}$ was calculated using $\mathrm{T}$ and $\mathrm{pCO}_{2}$ that were measured manually at this site on the days the site was visited and during November 2013 the data logger observations were used.

\section{RESULTS}

\section{Atmospheric changes at the weather station and inside Cueva Larga}

The mean annual temperature (MAT) measured over two years at the $C L$ weather station was $22.5 \pm 0.1^{\circ} \mathrm{C}$ $\left(22.5^{\circ} \mathrm{C}\right.$ between November 2012 and November 2013 and $22.4^{\circ} \mathrm{C}$ between November 2013 and November 2014; including adjusted $A O$ data to fill the gaps of the $C L$ weather station). The daily average temperatures at the $C L$ weather station ranged from a minimum of $17.5^{\circ} \mathrm{C}\left(25\right.$ December 2013) to a maximum of $27.2^{\circ} \mathrm{C}$ (1 October 2013). The annual range of daily average temperatures at the $C L$ weather station was $9.7^{\circ} \mathrm{C}$. Differences between daily minimum and maximum temperatures reach up to $15^{\circ} \mathrm{C}$.

Monitoring sites near the cave entrance $(\mathrm{A}, \mathrm{B}$ and C) exhibit variations in temperature exceeding $2^{\circ} \mathrm{C}$. At site D (240 $\mathrm{m}$ from the cave entrance) and site E (425 $\mathrm{m}$ from the cave entrance) the temperature variations were smaller than $1^{\circ} \mathrm{C}$. The mean temperature at site $\mathrm{E}\left(22.5 \pm 0.2^{\circ} \mathrm{C}\right)$ is indistinguishable from the $M A T$ $\left(22.5^{\circ} \mathrm{C}\right)$ measured outside the cave (Fig. 3). Outside temperature variations and possibly changes in the extension of thermal different air masses inside the entrance area appear to influence the first $150 \mathrm{~m}$ of the cave. No pronounced temperature variability is detected at distances greater than $240 \mathrm{~m}$ from the cave entrance.

Fig. 4A shows the seasonal variation in daily average temperatures at the $C L$ weather station compared to the temperature recorded inside the cave at site $\mathrm{E}$. The point measurments of temperature at site $\mathrm{E}$ are always close to the outside $\operatorname{MAT}\left(22.5^{\circ} \mathrm{C}\right)$ with a deviation not greater than $0.4^{\circ} \mathrm{C}\left(22.2\right.$ to $\left.22.9^{\circ} \mathrm{C}\right)$.

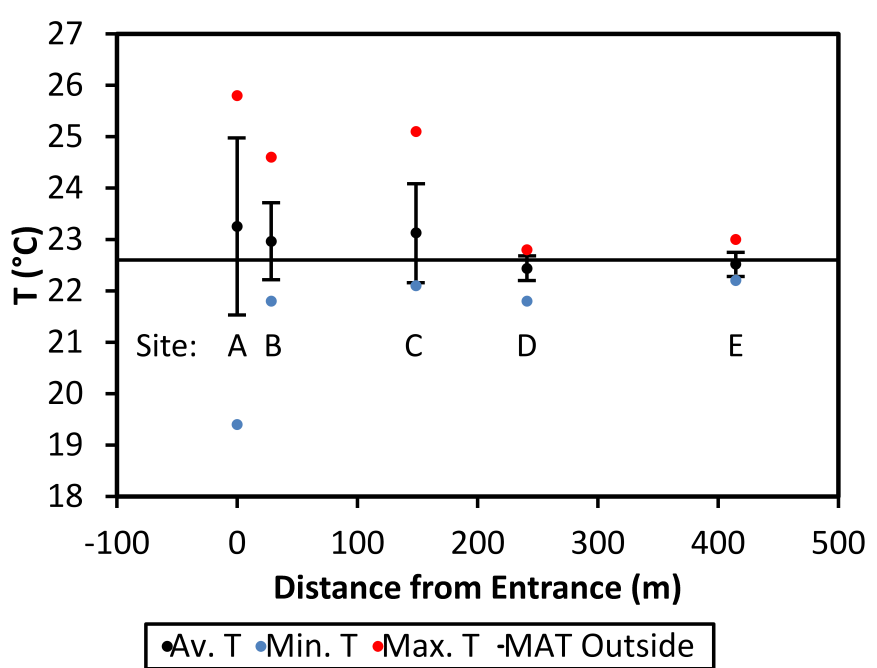

Fig. 3. Temperature observations in Cueva Larga. Points mark the average, minimum and maximum $T$ measurements at the monitored sites. Error bars of the average $T$ represent the standard deviation. The black line represents the MAT outside the cave. 


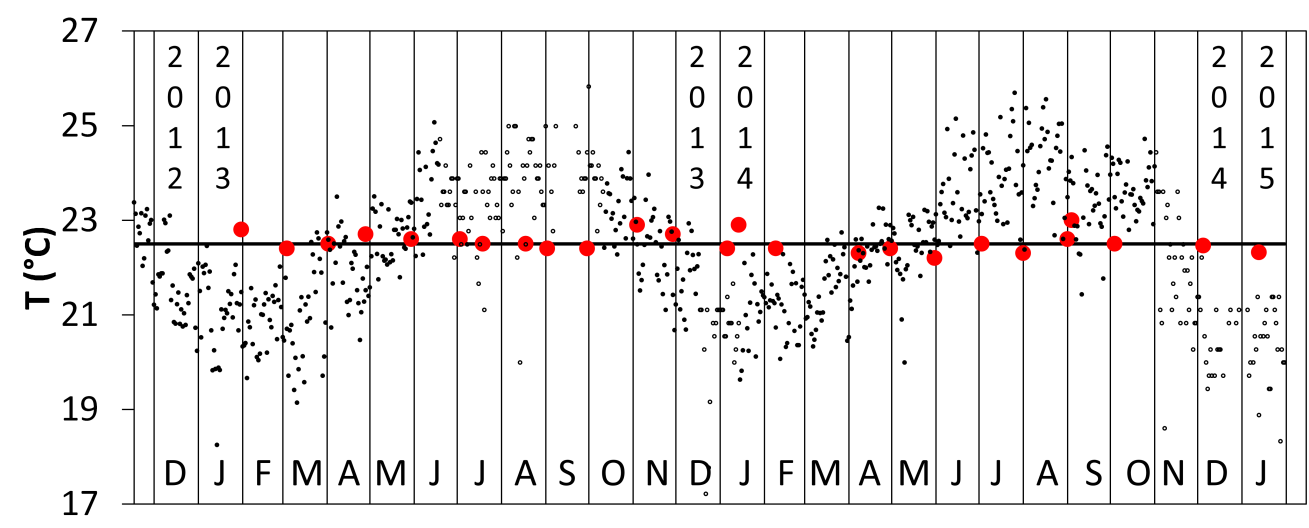

-T Site E $\quad$-T Weatherstation $\quad$-MAT outside $\quad$-Gaps (T Arecibo adjusted)

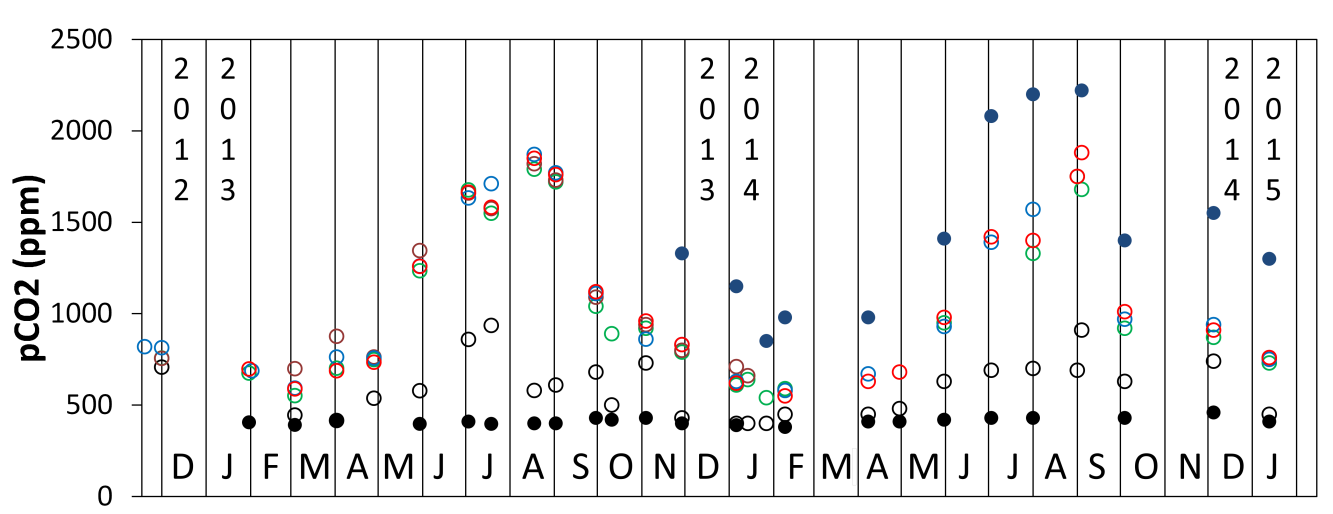

- Outside $\circ$ Site A (Entrance) $\circ$ Site B $\circ$ Site $C \circ$ Site D $\circ$ Site $E \bullet$ Collapse Room

Fig. 4. Annual cycle of $T$ and $p \mathrm{CO}_{2}$; Letters indicate the month of the year and the vertical arranged numbers are the calendar years. (A) average daily temperature at the Cueva Larga weather station (black points); missing data was replaced by adjusted data from the Arecibo Observatory (open circles, 19 Juni 2013 to 12 October 2013, 18 December 2013 to 14 January 13 and 2 November 2014 to 31 January 2015). Also shown is the MAT outside at the weather station (black line) and the temperature measured at the deep cave site $\mathrm{E}$ during each cave monitoring visit (red points, measurement accuracy of $0.2^{\circ} \mathrm{C}$ is equal to the points size); (B) Measurements of $\mathrm{pCO}_{2}$ values taken during each cave visit: colored open circles represent sites inside the cave; black open circles represent site $A$ at the cave entrance, black filled circles outside at the weather station and blue filled circle shows the upper passage in the collapse room at the end of the cave.

Relative humidity inside CL ranges between $82.2 \%$ and $100 \%$ (Fig. 2C). Values below 90\% are encountered up to $150 \mathrm{~m}$ inside the cave (Site C). At greater distances to the cave entrance the measurements are indistinguishable from 100\% considering the measurement error. At the distant site $\mathrm{E}$ the minimum value is $92.7 \%$, the maximum is $100 \%$ and the average value is $99.0 \%$.

Monthly $\mathrm{pCO}_{2}$ measurements recorded in $\mathrm{CL}$ (Sites B, C, D, and E) throughout the year (Fig. 4B) are in phase with the annual temperature cycle outside the cave (Fig. 4A). In $C L$ 's main passage the highest $\mathrm{pCO}_{2}$ values $(1,600$ to $1,850 \mathrm{ppm})$ occur during the warmer summer months between July and the beginning of September. Unlike temperature, the annual $\mathrm{pCO}_{2}$ pattern is not symmetrical. The $\mathrm{pCO}_{2}$ values show a gradual rise from May to August and a rapid decrease in September. The lowest $\mathrm{pCO}_{2}$ values are observed from December to March. At station A the $\mathrm{pCO}_{2}$ pattern is similar with a less pronounced summer maxima and mostly lower $\mathrm{pCO}_{2}$ values $(1,000 \mathrm{ppm}$ in summer and $400 \mathrm{ppm}$ in winter). At the cave entrance (station A) outside atmosphere dominates during the winter when it seeps into the cave. During the summer higher values inside the cave are accompanied by high values at the entrance linked to the slow dispersion of cave air during the summer when ventilation is low or absent. Since November 2013 the upper passage of the Collapse Room at the end of the cave has been visited monthly as well. Here the $\mathrm{pCO}_{2}$ values show the same seasonality as in the main passage and are elevated reaching about $900 \mathrm{ppm}$ in winter and up to $2,200 \mathrm{ppm}$ in summer (Fig. 4B). The highest $\mathrm{pCO}_{2}$ values have been measured in the smaller and lower passage below the main passage in the Collapse Room. Infrequent visits indicate that the $\mathrm{pCO}_{2}$ values seem to range between 2,300 and 3,600 ppm.

\section{Reconstructing ventilation patterns via temperature difference $d T$ and calculation of $T_{v}$}

The temperature difference between cave and outside temperature $d T$ is a commonly used indicator for buoyancy differences between cave and outside air (Fairchild \& Baker, 2012; Breitenbach et al., 2015; Ridley et al., 2015). A more precise measure of buoyancy is virtual temperature $T_{v}$ because $T_{v}$ includes the effect of variations in the primary molecular composition of each air mass to their buoyancy. Figure 5 shows the monitoring results from 2013 and 2014 , including the seasonal $p C O 2$ variation at site $\mathrm{E}$, daily average barometric pressure, $d T, T_{v}$ for cave site $\mathrm{E}$ and $T_{v}$ for the external atmosphere.

The temperature difference $d T$ was calculated between the cave temperature at site $\mathrm{E}\left(\sim 22.5^{\circ} \mathrm{C}\right)$ and 
the daily average outside temperature. Negative values occurred between October/November to May/June reaching as low as $-3.6^{\circ} \mathrm{C}$. Positive values dominated during the rest of the year reaching values as high as $5.3^{\circ} \mathrm{C}$.

Virtual temperature $T_{v}$ was calculated for inside and outside the cave (Equation 1). Outside the cave $T_{v}$ range was calculated at $10^{\circ} \mathrm{C}$ for the daily average data collected at the weather station. Minimum $T_{\nu}$ and maximum $T_{v}$ were calculated at $19.0^{\circ} \mathrm{C}$ on 21 December $2013\left(17.2^{\circ} \mathrm{C}, 82 \% R H\right.$ and $\left.400 \mathrm{ppm} p \mathrm{CO}_{2}\right)$ and $29.0^{\circ} \mathrm{C}$ on 20 September $2013\left(25.8^{\circ} \mathrm{C}, 82 \% R H\right.$ and $400 \mathrm{ppm} p \mathrm{CO}_{2}$ ), respectively. Cave $T_{v}$ was calculated for site $\mathrm{E}$ because it is the most representative site for undisturbed cave conditions inside the main passage due to the distance to the cave entrance and nearly invariant temperature. At site $\mathrm{E} T_{v}$ ranges only between 25.2 to $25.8^{\circ} \mathrm{C}$ (Fig. 5) despite the seasonal $p \mathrm{CO}_{2}$ cycle. Using constant values of $\mathrm{T}=22.5^{\circ} \mathrm{C}$ and $R H=100 \%$ the influence of the $p \mathrm{CO}_{2}$ variations on $T_{v}$ inside the cave was calculated to account for only $0.2^{\circ} \mathrm{C} T_{v}$ for the monitored period. The annual outside temperature cycle highly influenced the outside $T_{v}$ results (Fig. 5).

Outside's air buoyancy (represented by $T_{v}$ ) is greater than the buoyancy inside the cave when temperatures outside the cave are larger than inside the cave (represented by a negative $d T$ ).

To estimate the daily and monthly variability in $T_{\nu}$ we used the hourly $T$ and $p \mathrm{CO}_{2}$ measurements of the

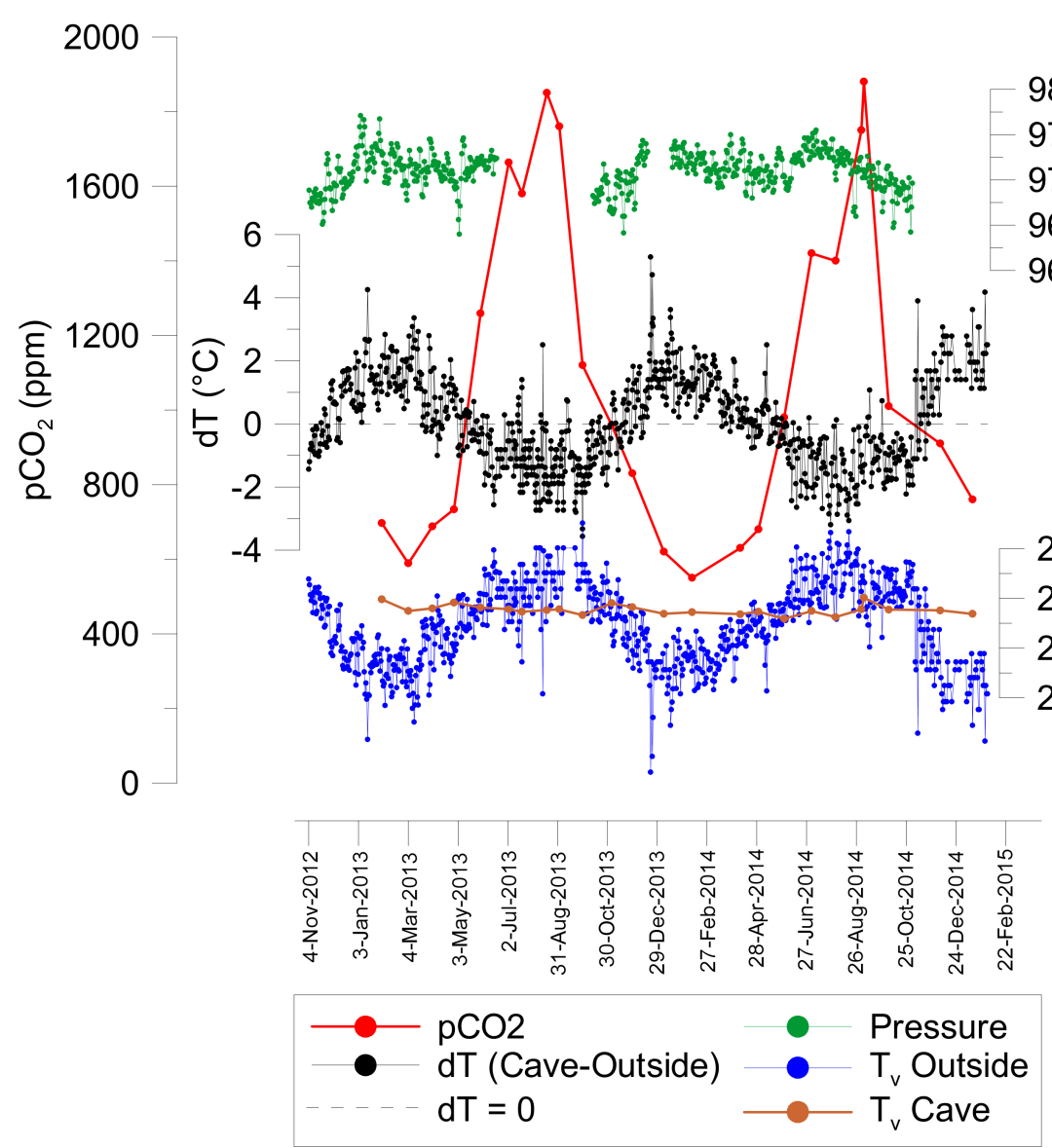

Fig. 5. The $\mathrm{pCO}_{2}$ seasonal cycle measured at the deep cave site $\mathrm{E}$ (red points) compared to atmospheric pressure (green points), temperature difference $d T$ between cave and outside (black points, the dashed line marks $d T=0$ ) and calculated virtual temperatures $T_{v}$ for the daily atmospheric observations at $C L$ weather station (blue points) and the cave atmosphere during each cave visit (brown points).
$\mathrm{CO}_{2}$ data logger at site $\mathrm{E}$, which are available from 4 November 2013 to 29 November 2013. Fig. 6 shows the calculated $T_{v}$ for measurements at Site $\mathrm{E}$ and at the weather station during 17 November 2013 and 18 November 2013. $T_{v}$ outside the cave is strongly dependent on the diurnal $T$ cycle while the $T_{v}$ inside the cave is invariant. During night-time atmospheric $T_{v}$ is below cave $T_{v}$ creating favorable conditions for more buoyant cave air to exit the cave. Despite possible night time ventilation, no significant variation in $\mathrm{pCO}_{2}$ has been recorded at the distant cave site $\mathrm{E}$. This suggests daily atmospheric temperature variations do not lead to noticeable ventilation in the main cave passage distant from the cave entrance because the cave air exchange time needed to effectively ventilate the cave is likely longer. During the 25 days of hourly observation the $\mathrm{pCO}_{2}$ inside the cave varies over a range of 200 ppm on a multi-diurnal to weekly time frame. This short-term variability is not co-occurring with changes in $d T$, but it occurs together with changes in atmospheric pressure. At low (high) pressure high (low) $\mathrm{pCO}_{2}$ values occurred at cave site $\mathrm{E}$. The long term observations (Fig. 5) show no seasonal cycle in atmospheric pressure and no co-variation between atmospheric pressure and long term $\mathrm{pCO}_{2}$.

Seasonal changes in diurnal buoyancy contrast were estimated by calculating the $T_{v}$ contrast between the cave and outside ( $T_{v}$ Cave - $T_{v}$ Outside) for twelve individual days from which actual field observations were available (Fig. 7). Positive buoyancy contrast (blue shading) indicates that there should be a high tendency for more buoyant cave air to leave the cave and to be replaced by less buoyant outside air. Negative buoyancy contrast (red shading), on the other hand, means that there is a high tendency of cave air to remain inside the cave. Our results can be grouped into three buoyancy contrast modes: winter (column 1), transition (column 2) and summer (column 3).

The winter mode is characterized by a positive buoyancy contrast exceeding $+5^{\circ} \mathrm{C}$ in $T_{v}$ during the night. A positive gradient of several degrees lasting up to 18 hours per day seems favorable for convective air exchange between the cave interior and exterior (winter mode). This likely generates the low $\mathrm{pCO}_{2}$ values measured in winter (Fig. 4). During the summer no marked positive buoyancy contrasts exists. Even during night hours the air outside the cave is occasionally more buoyant than inside and free convective air exchange is limited. The main differences between winter and summer mode are represented in insert 2 in Fig. 1 where arrows represent ventilation generated by more buoyant cave air leaving the cave during winter and the more stagnant 

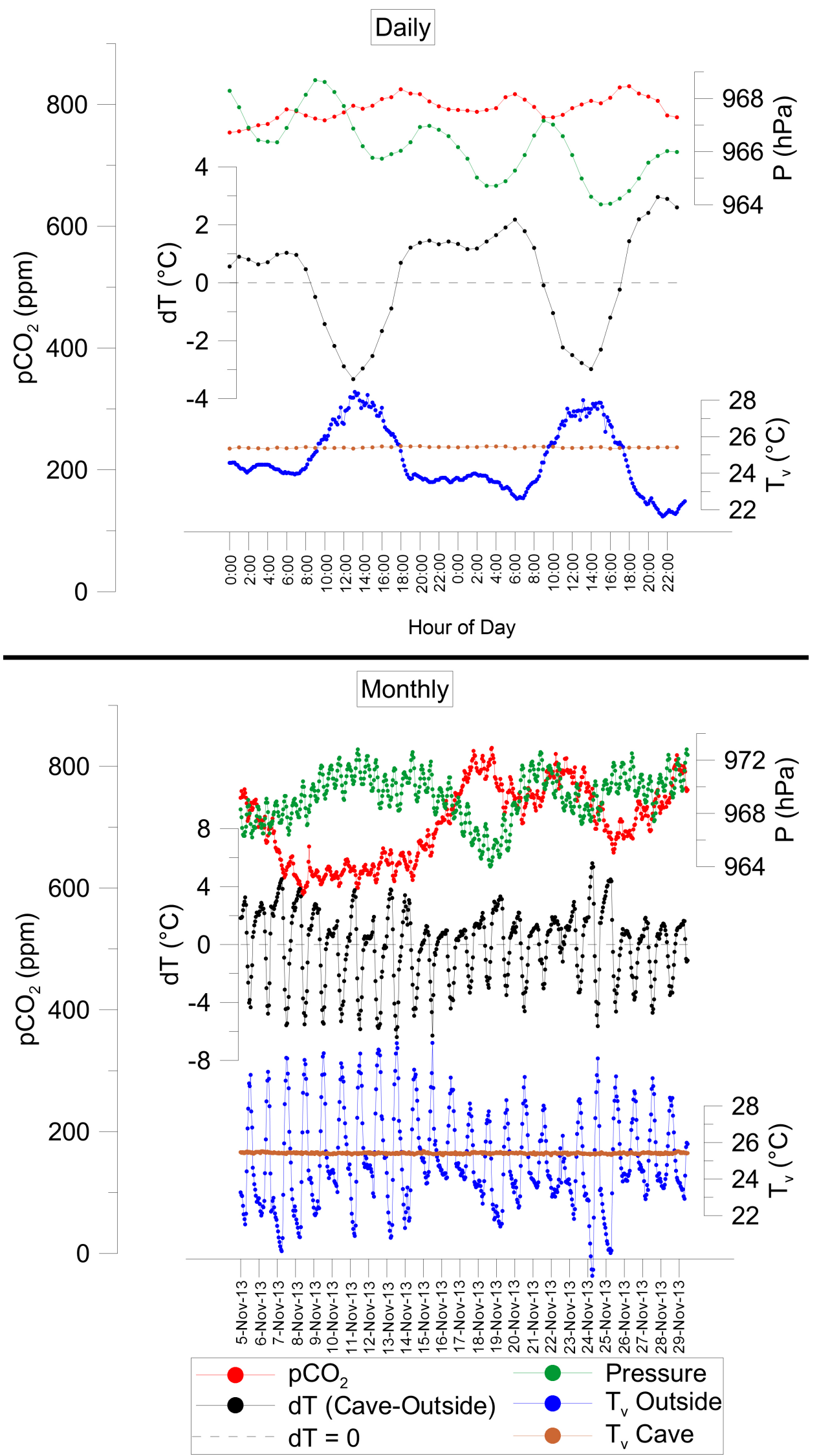

Fig. 6. Results of successful $\mathrm{CO}_{2}$ data logger deployment at site $\mathrm{E}$. Top shows the observations during two days (17 to 18 November 2013). Bottom shows the complete deployment period (5 to 29 November 2013). The hourly log of $p \mathrm{CO}_{2}$ (red) is compared to the average atmospheric pressure per hour (green), the temperature difference between cave and outside $d T$ (black, the dashed line marks $d T=0$ ) and the calculated $T_{v}$ inside the cave (brown) and outside the cave (blue). 

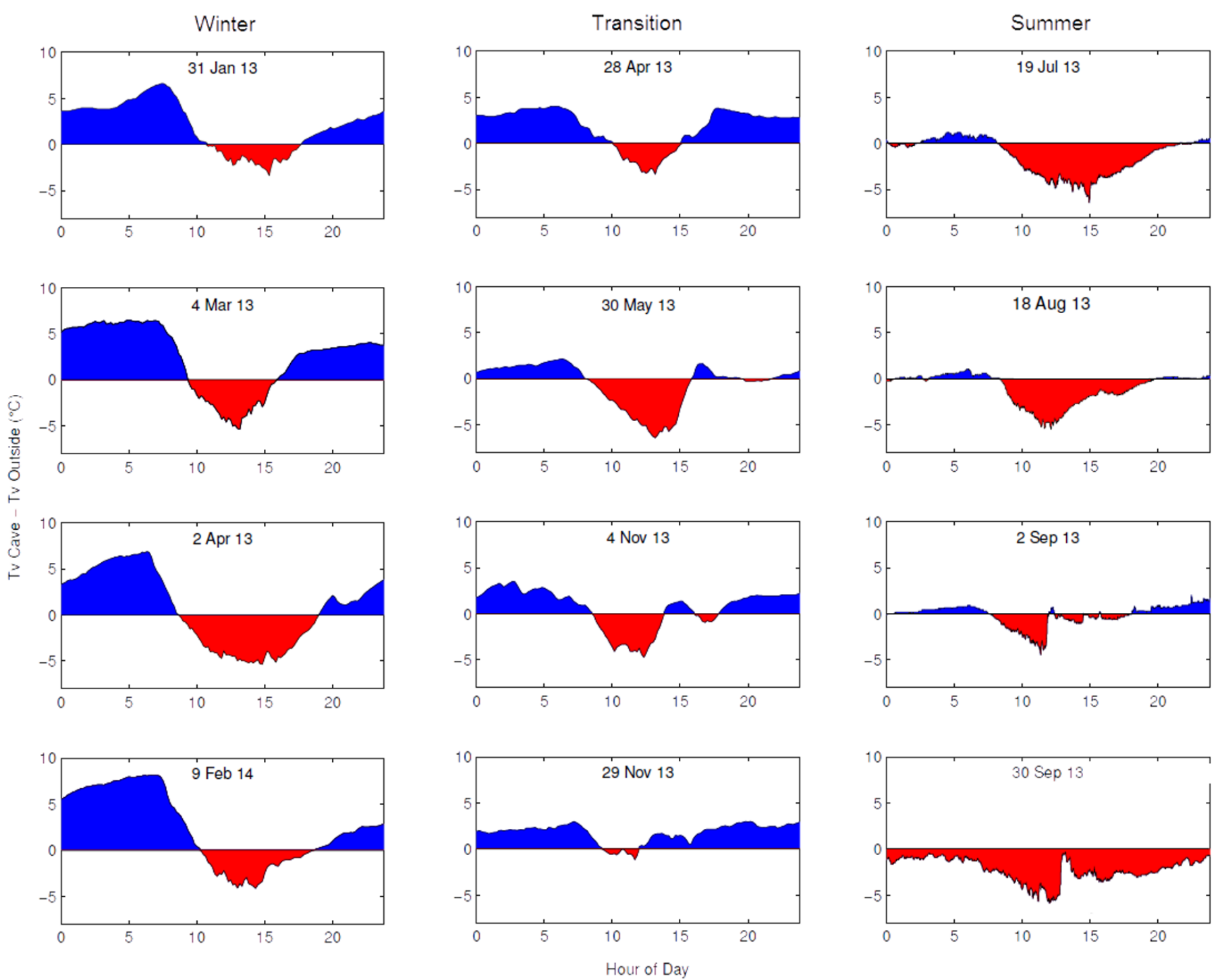

Fig. 7. Daily buoyancy contrast ( $T_{v}$ Cave $-T_{v}$ Outside) calculated for monthly cave visits for cave site E. Blue shading represents times of greater cave air buoyancy (possible cave ventilation) and red shading represents times of greater outside air buoyancy (stagnant air).

summer conditions when highest $\mathrm{pCO}_{2}$ values are represented by no air motion. The transition mode is characterized by a switch between diurnal dominant negative buoyancy contrast to positive buoyancy contrasts (favorable for ventilation) at night and negative (stagnant ventilation) during the day. Here the positive buoyancy contrasts does not exceed $+5^{\circ} \mathrm{C}$. Intermediate $\mathrm{pCO}_{2}$ values are measured during the transition mode inside $C L$.

\section{Cave air exchange time and ventilation rates}

Monthly monitoring data allows estimating cave air exchange times and ventilation rates for $C L$. To do so, the dynamic $C L$ ventilation pattern was simplified to a linear time invariant system. In this system the cave atmosphere responds to step changes in cave air ventilation rate from no ventilation in summer (ventilation rate $=0$ ) to maximum ventilation in winter. The resulting ventilation rate is a minimum estimate value because it may be possible that some ventilation may occur during the summer. In this case, the ventilation rate would be greater than our estimate. Two assumptions have been made: 1) The $\mathrm{CO}_{2}$-input is constant throughout the year; and 2) cave ventilation with the outside air is the only way to remove $\mathrm{CO}_{2}$ from the cave. The change in seasonal ventilation patterns can be described by an exponential decrease during fall/winter in cave atmosphere $\mathrm{pCO}_{2}$ :

$$
\begin{gathered}
\text { Winter } p \mathrm{CO}_{2} \text { Fall: } \\
p \mathrm{CO}_{2}(t)=\left\{\mathrm{CO}_{2}^{i}-p \mathrm{CO}_{2}^{f}\right\} * e^{-t / \tau}+p \mathrm{CO}_{2}^{f}
\end{gathered}
$$

where: $p \mathrm{CO}_{2}(t)=$ partial pressure of $\mathrm{CO}_{2}$ at time $t, p C O_{2}^{i}=$ initial partial pressure of $\mathrm{CO}_{2}$ in $\mathrm{ppm}$, $p \mathrm{CO}_{2}^{f}=$ final partial pressure of $\mathrm{CO}_{2}$ in ppm, $\tau=$ system time constant in days, and $t=$ time in days.

The system time constant $\tau$ (Equation 2) corresponds to the cave air exchange time (Frisia et al., 2011). It was calculated via a non-linear least-square fit model by minimizing the sum of squared residuals for all $\mathrm{pCO}_{2}$ measurements from 2013 and 2014, taking the individual measurement errors into account (Fig. 8). To compare the result, the fit was also performed for each single season and year, respectively (Table 1). The start of the winter fall in the $\mathrm{CO}_{2}$ curve was set to the last maximum measurement before the exponential decline $=1,880$ ppm (04-Sept-2014) and the end of the exponential decline was set to the lowest measured value of $=620 \mathrm{ppm}$ (06-Jan-2014). For seasons of the single years, the initial and final values where chosen in an analogous manner. For a better overview the results of 
all fits are shown in Table 1 . The resulting values for cave air exchange time during the winter ventilation season is $\tau_{\text {winter }}=36 \pm 5$ days. Fig. 8 shows the resulting fit curves for all cases. Our cave air exchange time agrees with the cave air exchange time estimates for each single year within the range of the standard error, respectively (Table 1), ensuring that our estimation does not vary among years. The performed least square estimation of the cave air exchange time is well constrained because all measurements with one exception fall within the $1 \mathrm{MSE}$ confidence level (Fig. 8).

Table 1. Results of the nonlinear least square fit of $\mathrm{pCO}_{2}$ measurements for different time periods in Cueva Larga to estimate the cave air exchange time $\tau$. Errors are calculated as mean squared error of the residuals (MSE) for the fit curve $p \mathrm{CO}_{2}(\mathrm{t})$ and as standard error (SE) for the estimated parameter $\tau$.

\begin{tabular}{|c|c|c|c|c|c|}
\cline { 2 - 6 } \multicolumn{1}{c|}{} & $\mathrm{pCO}_{2}^{\mathrm{i}}(\mathrm{ppm})$ & $\mathrm{pCO}_{2}^{\mathrm{f}}(\mathrm{ppm})$ & $\tau$ (days) & $\mathrm{SE}($ days $)$ & $\mathrm{MSE}(\mathrm{ppm})$ \\
\hline $2013 / 14$ & $1880(18$-Aug-2013) & $620(06-\mathrm{Jan}-2014)$ & 36.87 & 6.03 & 116.7 \\
\hline $2014 / 15$ & $1880($ 04-Sep-2014) & $620(19-$-Apr-2015) & 35.18 & 8.25 & 122.6 \\
\hline Both years & $1880(18$-Aug-2013) & $620(6-J a n-2014)$ & 35.56 & 4.41 & 103.0 \\
\hline
\end{tabular}

\section{pCO2 fit winter mode}

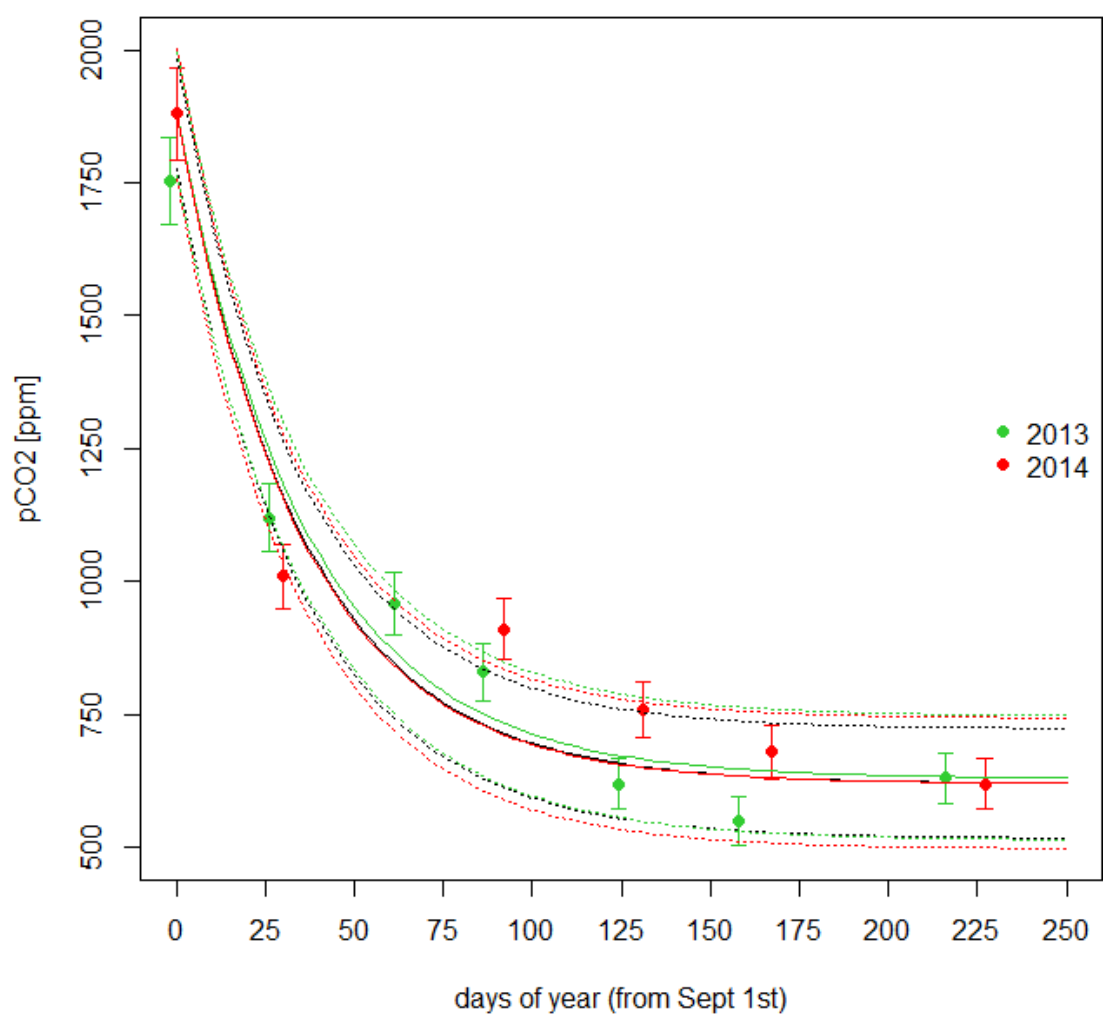

Fig. 8. Curve fitting to estimate the cave air exchange time via the system time constant $\tau$ of CL. Colored curves show the fit curves of data from 2013/14 (green) and 2014/15 (red). The black curve indicates the fit for 2013 and 2014 together. Dotted lines mark the mean squared error confidence bands (1MSE), respectively. Reference date is 01-Sept.

the cave (positive $d T$; greater cave $T_{v}$ ) air convection (cave ventilation) is induced and cave air moves from the cave towards the outside and is replaced by less buoyant outside air with "low" atmospheric $\mathrm{pCO}_{2}$ concentration. Conversely, when buoyancy is lower in the cave than outside the cave (negative $d T$; lower cave $T_{v}$ ), the air column is stable and cave ventilation is at a minimum due to stagnation of temperature driven ventilation. Without temperature driven ventilation surface pressure variations can cause minimal ventilation (Baldini et al., 2006) which in the case of $\mathrm{CL}$ does not match the $\mathrm{CO}_{2}$ input and $\mathrm{CO}_{2}$ accumulates inside the cave (Fig. 5).

The seasonal temperature change outside $C L$ appears to be the principal controller on the observed annual $\mathrm{pCO}_{2}$ cycle. Outside the cave $T_{v}$ follows the seasonal temperature cycle and its range is an order of magnitude greater than in the cave. In $C L, d T$ and $T_{v}$ calculations show the same seasonal and diurnal buoyancy changes between cave and outside. At this site $d T$ calculations are valid estimation of buoyancy differences between cave and outside air despite the fact that $d T$ does not take variations of

Using an estimation of the cave volume based on survey data from Miller (2010) allows a rough calculation of the ventilation rate during winter. The volume is approximately $120,000 \mathrm{~m}^{3}$ with a conservative error estimation of $20 \%$. Dividing the cave volume by the cave air exchange time $(36 \pm 5$ days) results in a cave ventilation rate of $3,300 \pm$ $1,000 \mathrm{~m}^{3} /$ day.

\section{DISCUSSION}

Two years of monitoring provide evidence for cave ventilation conditions during winter and nearstagnant ventilation conditions during summer in $C L$, Puerto Rico. The seasonal ventilation changes are accompanied by high maximum $\mathrm{pCO}_{2}$ values in late summer and minimum $\mathrm{pCO}_{2}$ values in the winter. When air buoyancy is higher in the cave than outside
$\mathrm{pCO}_{2}$ and $\mathrm{RH}$ into account. The buoyancy effect of seasonal $\mathrm{pCO}_{2}$ variations in $C L$ does not oppose the seasonal $d T$ cycle, because the summer $\mathrm{pCO}_{2}$ maxima inside $C L$, similar as the higher summer temperature outside $C L$, decreases the cave air's buoyancy compared to the buoyancy of outside air. Significant deviations between $T_{v}$ and $d T$ buoyancy examinations are expected at locations with temporal different cave $p \mathrm{CO}_{2}$ variations and where cave $p \mathrm{CO}_{2}$ reaches higher values then in CL (Sánchez-Cañete et al., 2013).

Our method to collect point measurements inside $C L$ once every month to investigate seasonal changes inside the cave appears appropriate because the $\mathrm{pCO}_{2}$ logging data does not show any diurnal $\mathrm{pCO}_{2}$ cycle (Fig. 6). The hourly logging observations were taken in November of 2013 during the transition from summer to winter ventilation mode. If a diurnal $p \mathrm{CO}_{2}$ cycle did occur in the main chamber in $C L$, 
it would be expected to be especially pronounced during the transition ventilation mode because the shift towards the well ventilated winter mode would occur predominantly during the night when unstable density conditions between cave and outside air favor air exchange. During this time no diurnal variation in $p \mathrm{CO}_{2}$ is detected, indicating that the main chamber is ventilated via a slower air exchange process filtering out the diurnal change from stable (day) to unstable (night) air density gradient. Thus, our quasi-monthly point measurements represent a time period of at least one day.

A model study by James et al. (2015) predicts little or no seasonal changes in ventilation and cave atmosphere $\mathrm{pCO}_{2}$ for tropical sites. In contrast, $C L$ exhibits a seasonal cave atmosphere $\mathrm{CO}_{2}$ cycle similar in magnitude to observations from temperate regions (Frisia et al., 2011; Spötl et al., 2005). Other caves from higher latitudes with similar ventilation systematics but different $\mathrm{CO}_{2}$ amplitudes have been observed such as in Austria (Boch \& Spötl, 2008), Ireland (Baldini et al., 2008), France (Bourges et al., 2006), Arizona, USA (Buecher, 1999), Texas, USA (Cowan et al., 2013) and Germany (Meisner et al., 2010). Yok Balum Cave in tropical Belize also shows seasonal ventilation differences (Ridley et al., 2015). Similar as in CL, low $\mathrm{pCO}_{2}$ values occur in Yok Balum during the winter where ventilation is more continuous than during the summer where diurnal variations cause $\mathrm{pCO}_{2}$ values of about 700 ppm. Unlike CL, Yok Balum Cave has two entrances at different altitudes preventing ventilation stagnation despite the on average higher outside temperatures during the summer due to density driven flow through the cave (Ridley et al., 2015). These two tropical sites show that seasonal or higher resolution field observations are inevitable for a correct site description and prediction of cave ventilation processes.

Other types of $\mathrm{pCO}_{2}$ systematics have also been documented. A very dynamic ventilated cave with diurnal and seasonal ventilation patterns is Mawmluh Cave in northeast India (Breitenbach et al., 2015). Stable $\mathrm{pCO}_{2}$ conditions exist in Castañar de Ibor Cave, Spain (Fernandez-Cortes et al., 2009) and in Bunker Cave, Germany (Riechelmann et al., 2011) which has constant ventilation during the whole year likely caused by two cave entrances at different altitudes. Caves in Gibraltar, near the sea level such as Ragged Staff Cave show a similar seasonal $\mathrm{pCO}_{2}$ cycle as in $C L$ and elevated caves above sea level such as St. Michaels Cave show an opposite $\mathrm{pCO}_{2}$ seasonality where maxima occur during the winter (Mattey et al., 2010, 2016). Similar observations come from Candamo Cave, Spain (Hoyos et al., 1998). The host rock of both locations has high porosity allowing air from the surface to reach the cave during the summer; this is not the case in the dense Lares Limestone hosting $C L$. Here, the air exchange with external air is restricted to the single cave entrance.

Numerous examples indicate that cave geometry is an important controlling factor on cave ventilation patterns (Geiger, 1961; Pflitsch \& Piasecki, 2003; Fairchild \& Baker, 2012; Gregorič et al., 2013).
Diurnal variations in temperature and $\mathrm{pCO}_{2}$ have been observed in other caves such as Ballynamintra Cave, Ireland (Baldini et al., 2008) and caves in central Texas (Cowan et al., 2013). In Ballynamintra Cave, diurnal $p \mathrm{CO}_{2}$ changes of up to 1,200 ppm have been observed. It has two entrances, located at the upper and lower cave level, and is significantly smaller than $C L$. This geometry seems to be responsible for the strong diurnal ventilation changes and near atmospheric $\mathrm{pCO}_{2}$ concentrations during the night. Buoyant cave air is likely to escape the cave through the upper entrance during the night while less buoyant air flows into the lower entrance inducing a rapid air stream through the cave. This is not the case in $C L$. In tropical settings, as $C L$, the seasonal variation in daily atmospheric average temperatures at the surface is smaller than the daily temperature cycle between day and night (Tarhule-Lips \& Ford, 1998). Although we only have hourly $\mathrm{pCO}_{2}$ measurements for 25 days, there is no indication that the $\mathrm{pCO}_{2}$ in $C L$ 's main passage responds to the daily temperature cycle because additionally to the hourly measurements in November 2013 there is no spatial variation on $\mathrm{pCO}_{2}$ throughout the main chamber at any point in time. Thus, we deduce that ventilation processes are driven primarily by seasonal differences between buoyancy inside and outside the cave as we have shown for the monthly observations. It is likely that the particular cave geometry of $C L$ prevents pronounced diurnal cave ventilation. Fig. 1 (insert 3) shows $C L$ 's vertical cross-section. Two "U" shaped structures are visible at the cave roof about $150 \mathrm{~m}$ into the cave between the entrance and site $\mathrm{C}$ (Fig. 1). Probably fast air movement is restricted due to the obstacles in the cave's entrance similar to observations by Baldini et al. (2006). In other caves, evidence exists for daytime ventilation even during the summer (e.g., Cowan et al., 2013; Breitenbach et al., 2015), while in CL the obstructed entrance and the lower summer cave air's buoyancy create a calm and stable air-mass in the entrance. We confirmed this on a summer day in 2016 via vertical temperature measurements (constant temperature) and a free falling plastic foil, which showed no horizontal drift while falling through the air column. Effective exchange between cave and outside air in $C L$ would require overcoming the " $U$ " shaped obstacles. This seems to occur predominantly during winter when the air buoyancy in the cave is greater than outside. Especially during winter nights the buoyancy contrast between cave and outside air is positive and cave air moves more easily through the "U" shaped flow path out of the cave. The lowest $\mathrm{pCO}_{2}$ value measured in $C L$ was $580 \mathrm{ppm}$. Thus under current climate conditions the cave never becomes completely flushed with atmospheric air ( 400 ppm). This might have been different during the geological past. If the temperature contrast between cave and outside had been greater than today, especially during the well ventilated winter season, more intense ventilation than at present could occur. Such a scenario may have been possible during cold events where temperatures have been shown to decrease by about $4^{\circ} \mathrm{C}$ in the tropics (Arienzo et 
al., 2015). But it seems likely that an increased caveoutside temperature gradient might have only existed during times of rapid temperature declines because caves will adopt the mean annual temperature of their environment on decadal timescales (Perrier et al., 2005; Genty, 2008) which are relatively short compared to the length of cold intervals. Our study shows that seasonality has a dominant effect on cave ventilation changes. Increased seasonality seems to be another possible scenario for increased winter ventilation.

Higher than atmospheric winter $p \mathrm{CO}_{2}$ values seem to be linked to the cave morphology of $C L$. The single entrance and the "U" shaped roof structures trap air inside the cave and hinder rapid air exchange under present climate conditions. Note that the buoyancy contrast curve for 30 September 2013 (Fig. 7) shows only negative values, but the $\mathrm{pCO}_{2}$ value inside the cave has already reached an intermediate value indicative of some cave ventilation (Fig. 5). This observation is most likely linked to cold weather periods before the field trip causing a short term increase in cave ventilation. The monitoring in 2014 shows similar observations. The $\mathrm{pCO}_{2}$ rise ceases in July 2014 where mean outside $T_{v}$ were similar to cave $T_{v}$ possibly allowing night time ventilation. The onset of the 2014 decrease in $\mathrm{pCO}_{2}$ also takes place in September similar to 2013. Several consecutive days in September have lower mean outside $T_{v}$ values than cave $T_{v}$ values, likely promoting cave ventilation and the onset of the transition mode. Thus our estimation of cave air exchange time is a maximum estimate since weather phenomena lasting several days seem to affect the ventilation system. More frequent observations are needed to get a more robust cave air exchange estimate.

In the main passage no spatial variation in cave atmosphere $\mathrm{CO}_{2}$ concentration was observed as documented for other caves (Baldini et al., 2006; Cowan et al., 2013). The lack of diurnal and spatial $p \mathrm{CO}_{2}$ variations are linked to the long cave air exchange time of about $36 \pm 5$ days because diurnal ventilation processes are dampened inside the large main passage of $C L$ leading to a well-mixed and homogeneous cave atmosphere. A simple measurement of vertical temperature profiles during a summer day in 2016 near the entrance and at the end of the main passage revealed no significant temperature variations. This strengthens the interpretation of a homogeneous cave atmosphere. Cave air exchange time of similar magnitude (54 days) and air exchange rate $(2,400$ $\mathrm{m}^{3}$ /day compared to $3,300 \mathrm{~m}^{3} /$ day in $\mathrm{CL}$ ) have been estimated for the Throne Room in the Kartchner Caverns (Buecher, 1999). In contrast, smaller caves seem to have faster exchange times. Cave chambers of flank margin caves on nearby Mona Island are estimated to have air exchange times of less than one hour (Vieten et al., 2016). These caves have several openings towards the island's cliff and sky lights which promote fast air exchange. Another smaller cave than $C L$ is Grotto di Ernesto (about 13,000 $\mathrm{m}^{3}$ ) which has an estimated exchange time of 1.4 days (Frisia et al., 2011). The large volume of $C L$, its tubular shape and the obstructed cave entrance geometry seem to be the key parameters for the observed seasonal ventilation pattern with well-mixed cave atmosphere. To understand the effect of the obstructed cave geometry in more detail higher spatial monitoring in the entrance zone should be conducted to investigate also the possible formation of distinct thermal zones, obstructing the ventilation process.

This study did not investigate soil $\mathrm{CO}_{2}$ production. Baldini et al. (2008) found evidence for soil-temperature induced changes in soil $\mathrm{pCO}_{2}$ production driving seasonal cave air $\mathrm{pCO}_{2}$ variations at a temperate location in Ireland. Changes in $\mathrm{pCO}_{2}$ production in the soil could be an addition to the observed seasonal $\mathrm{pCO}_{2}$ pattern, but seem to be of minor importance compared to changes in cave ventilation at this tropical site. Similar conclusions have been made at numerous other sites ( De Freitas et al., 1982; Pflitsch \& Piasecki, 2003; Spötl et al., 2005; Kowalczk \& Froelich, 2010; Cowan et al., 2013; Gregorič et al., 2013). Mattey et al. (2016) found that decay of organic matter washed down into the unsaturated zone appears to be a $\mathrm{CO}_{2}$ source of similar importance, which is likely to be annually constant. Drip site studies in $C L$ (Vieten et al., accepted) show that variations in element concentration in the drip water appear constant, implying that the $\mathrm{CO}_{2}$ input remains constant throughout the year. Additional support for our assertion of seasonal temperature variations controlling cave ventilation is the strong drop in cave air $\mathrm{pCO}_{2}$ from about $1,900 \mathrm{ppm}$ to about 600 ppm during the summer-winter transition because increased ventilation transports atmospheric, low $\mathrm{pCO}_{2}$ air into the cave. During the winter-summer transition the gradient between cave and atmospheric air is small compared to the summer-winter transition, thus the decreasing ventilation is accompanied by a less rapid increase in $\mathrm{pCO}_{2}$

Mammals and aerobic bacteria are another source of $\mathrm{CO}_{2}$ inside $\mathrm{CL}$, besides the $\mathrm{CO}_{2}$ input from drip water degassing into the cave atmosphere. Their $\mathrm{CO}_{2}$-producing activities include respiration and the decay of fecal and biological matter introduced into the cave. Bats and rats live in $C L$ and their population size is approximated to range between 200 and 500 individuals. We consider their influence to the seasonal $\mathrm{pCO}_{2}$ cycle as an insignificant contribution because their population size does not vary seasonal at this site and estimating the input of $\mathrm{CO}_{2}$ by respiration of bats via the field metabolic rate (FMR) and the energy balance shows that a few hundred thousand bats should live during the summer in the cave to explain an annual $\mathrm{CO}_{2}$ increase of more than $1,200 \mathrm{ppm}$ during transition from winter to summer (Neuweiler, 2000).

The highest $\mathrm{pCO}_{2}$ values are measured in the Collapse Room at the end of the cave. This is not surprising because usually $\mathrm{CO}_{2}$ accumulates with distance from the cave entrance (Baldini et al., 2006; Cowan et al., 2013). In $C L$ the ventilation of the Collapse Room seems to be less effective compared to the main passage because an elevation on the cave floor (Fig. 1) divides the Collapse Room from the main 
passage. Maximal $\mathrm{pCO}_{2}$ values are reached in the lower passage of the Collapse Room which suggests that it's small geometry at the cave end forms a calmer air mass with less effective ventilation as in the upper Collapse Room and the main passages of $C L$, similar to other caves (Baldini et al., 2006; Badino, 2009).

Atmospheric pressure variations have an influence on the $\mathrm{pCO}_{2}$ concentration at site $\mathrm{E}$ on timescales of days to weeks. Over the logging period we observed a $\mathrm{CO}_{2}$ variability of up to $200 \mathrm{ppm}$ related to atmospheric pressure changes. The hourly $\mathrm{pCO}_{2} \log$ from November 2013 (Fig. 6) shows that low atmospheric pressure systems are accompanied by high $\mathrm{pCO}_{2}$ values at site $\mathrm{E}$ and vice versa. Similar as in Ballynamintra Cave, Ireland (Baldini et al., 2006), this observation appears to be relate to the air mass with high $\mathrm{pCO}_{2}$ values at the end of the cave in the Collapse Room. When the atmospheric pressure decreases, the air in the back of the cave expands into the main cave passage where it increases the $\mathrm{CO}_{2}$ concentration. In addition, the low pressure might pull out air from fractures and fissures which has high $\mathrm{pCO}_{2}$ values. While a high pressure system provides additional cave ventilation by pushing atmospheric, low $\mathrm{pCO}_{2}$, air into the cave which lowers the cave atmosphere $\mathrm{pCO}_{2}$. In Castañar de Ibor Cave a major atmospheric low pressure event lowered cave $\mathrm{pCO}_{2}$ via increasing cave ventilation (Fernandez-Cortes et al., 2009), such a major event did not occur over the monitored time frame in $C L$. Similar observations come from another site in Spain, Candamo Cave, where low atmospheric pressure systems during the winter are related to lower cave $\mathrm{pCO}_{2}$ (Hoyos et al., 1998). The long term observations (Fig. 5) do not show a relationship between the seasonal $\mathrm{pCO}_{2}$ cycle and atmospheric pressure, thus the primary driver of long term cave ventilation is the seasonal temperature change outside the cave. On a daily time scale (Fig. 6) a semidiurnal oscillation appears in the hourly $\mathrm{CO}_{2}$ log, but its amplitude is smaller than the logger's accuracy. This signal appears to be authentic, because it shows a similar anti-correlation to the atmospheric tides (Lindzen, 1979) as the monthly $\mathrm{CO}_{2}$-log does to the atmospheric pressure systems, discussed above. Evidence for atmospheric tides influencing cave temperatures has been found in caves in France (Bourges et al., 2006). In the Roseland Tunnel in the French Alps (Richon et al., 2009), atmospheric tidal signal is evident in the underground radon-concentration and in drip water flow rates, similar to Père Noël cave in Belgium (Genty \& Deflandre, 1998), but at these locations no related variation in the underground $\mathrm{CO}_{2}$ concentrations were documented.

Speleothems are frequently used as climate archives (Wang et al., 2001; Lachniet et al., 2004, Winter et al., 2011). Cave monitoring has important implications for the robust interpretation of speleothem climate records. In general, cave temperatures are assumed to be constant over the year and equal to the MAT outside the cave (Fairchild et al., 2006). It is well known that seasonal and diurnal temperature variations are encountered near the cave entrances. Temperature measurements in $C L$ show considerably temperatures variation $\left(>2^{\circ} \mathrm{C}\right)$ near the cave entrance which can cause noise in the speleothem proxy record of up to $-0.23 \%$ o ${ }^{\circ} \mathrm{C}^{-1}$ (Lachniet, 2009). Annual constant temperatures exist at a distance greater than $200 \mathrm{~m}$ from the entrance (Fig. 2). In $C L$ and in similar settings speleothems should be taken at larger distances than $200 \mathrm{~m}$ of the cave entrances, if they cannot be analyzed at seasonal or higher resolution.

Seasonal differences in cave atmosphere parameters can change carbonate precipitation rates (e.g., Kaufmann \& Dreybrodt, 2004; Fairchild et al., 2006; Baldini et al., 2008). The $\mathrm{CO}_{2}$ concentration of cave atmosphere is directly linked to the growth rate of stalagmites (Dreybrodt, 2012; Baker et al., 2014). Growth rate variations can bias the speleothem climate record and lead to changes in the incorporation of trace elements into the crystal lattice (Fairchild et al., 2006; Gabitov \& Watson, 2006). Increased cave ventilation leads to lower $\mathrm{pCO}_{2}$ values in the cave atmosphere and accordingly lower calcium equilibrium concentration which increases carbonate precipitation rates (Baker et al., 2014). Even though it rains more in the summer, speleothems in $C L$ are expected to grow faster during the low $\mathrm{pCO}_{2}$ winter season, all other things being equal. This is important if the drip site has a fast response time to rainfall events above the cave. In the extreme case, speleothems in $C L$ could only grow during the winter and fast responding drip sites will only record a winter environmental signal in the speleothem's carbonate. To quantify the seasonal growth bias in $C L$ further studies are needed which investigate the $\mathrm{Ca}^{2+}$-ion concentrations in the drip water throughout the year, the water film thicknesses and drip rates (Baldini et al., 2008).

\section{CONCLUSION}

Monthly monitoring of the cave atmosphere and high-resolution logger data enabled us to quantify changes in cave air $\mathrm{pCO}_{2}$ in $C L$, Puerto Rico. The largest variation occurs on the seasonal scale with $p \mathrm{CO}_{2}$ maxima in summer and minima in winter. This seasonal pattern is mainly driven by the seasonal cycle in surface temperature, as is evident from calculation of temperature differences and virtual temperature contrasts between the cave and the surface. During summer, when surface temperature is warmer than cave temperature, cave ventilation is suppressed, leading to accumulation of $\mathrm{CO}_{2}$. During the transition from summer to winter, and especially during winter, the positive buoyancy contrast between the cave and the surface promotes cave ventilation leading to lower $p \mathrm{CO}_{2}$. On shorter time scales (diurnal to weekly), cave air $\mathrm{pCO}_{2}$ is also influenced by atmospheric pressure changes.

\section{ACKNOWLEDGMENTS}

This research was supported in part by grant AGS 1003502 from the National Science Foundation. R. Vieten is thankful to the International Association of Sedimentology for supporting the field work via a Postgraduate Grant. D. Scholz and S. Warken are 
grateful to the DFG for funding (SCHO 1274/6-1). We thank Sylvia Riechelmann and Adrian Immenhauser from the Ruhr University Bochum and Eric Harmsen from the University of Puerto Rico, Mayaguez for their technical support. We thank Augusto Mangini from the University of Heidelberg and Christoph Spötl from the University of Innsbruck for their support in the field and for helpful discussions. We thank the anonymous reviewers for thorough and constructive comments which significantly improved the manuscript. We thank Felipe Rodriguez-Morales and his family for their support of the Cueva Larga cave monitoring program and Nestor Aponte and Phil Perillat from the Arecibo Observatory. We also thank Juan Estrella Martinez, Flora Sperberg, Sarymar Barreto Saavedra, Jeff Kruse, Michael A. Casciano Kotick, Jose A. Santiago-Saez, Brett Isham and Monica Larson for their assistance in the field.

\section{REFERENCES}

Arienzo M.M., Swart P.K., Pourmand A., Broad K., Clement A.C., Murphy L.N., Vonhof H.B. \& Kakuk B., 2015 - Bahamian speleothem reveals temperature decrease associated with Heinrich stadials. Earth and Planetary Science Letters, 430: 377-386.

http://dx.doi.org/10.1016/j.eps1.2015.08.035

Badino G., 2009 - The legend of carbon dioxide heaviness. Journal of Cave and Karst Studies, 71: 100-107.

Baker A.J., Mattey D.P. \& Baldini J.U.L., 2014 Reconstructing modern stalagmite growth from cave monitoring, local meteorology, and experimental measurements of dripwater films. Earth and Planetary Science Letters, 392: 239-249.

http://dx.doi.org/10.1016/j.eps1.2014.02.036

Baldini J.U.L., Baldini L.M., McDermott F. \& Clipson N., 2006 - Carbon dioxide sources, sinks, and spatial variability in shallow temperate zone caves: Evidence from Ballynamintra Cave, Ireland. Journal of Cave and Karst Studies, 68: 4-11.

Baldini J.U.L., McDermott F., Hoffmann D.L., Richards D.A. \& Clipson N., 2008 - Very high-frequency and seasonal cave atmosphere $\mathrm{PCO}_{2}$ variability: Implications for stalagmite growth and oxygen isotope-based paleoclimate records. Earth and Planetary Science Letters, 272: 118-129.

http://dx.doi.org/10.1016/j.eps1.2008.04.031

Boch R. \& Spötl C., 2008 - The origin of lamination in stalagmites from Katerloch Cave, Austria: Towards a seasonality proxy. Pages News, 16: 21-22.

Bourges F., Genthon P., Mangin A. \& D'Hulst D., 2006 - Microclimates of l'Aven d'Orgnac and other French limestone caves (Chauvet, Esparros, Marsoulas). International Journal of Climatology, 26: 1651-1670. http://dx.doi.org/10.1002/joc. 1327

Breecker D.O., Payne A.E., Quade J., Banner J.L., Ball C.E., Meyer K.W. \& Cowan B.D., 2012 - The sources and sinks of $\mathrm{CO}_{2}$ in caves under mixed woodland and grassland vegetation. Geochimica et Cosmochimica Acta, 96: 230-246.

http://dx.doi.org/10.1016/j.gca.2012.08.023

Breitenbach S.F.M., Lechleitner F. a., Meyer H., Diengdoh G., Mattey D. \& Marwan N., 2015 - Cave ventilation and rainfall signals in dripwater in a monsoonal setting - a monitoring study from NE India. Chemical Geology, 402: 111-124.

http://dx.doi.org/10.1016/j.chemgeo.2015.03.011
Buecher R.H., 1999 - Microclimate study of Kartchner Caverns, Arizona. Journal of Archaeological Science, 61: 108-120.

Cowan B.D., Osborne M.C. \& Banner J.L., 2013 Temporal variability of cave-air $\mathrm{CO}_{2}$ in central Texas. Journal of Cave and Karst Studies, 75: 38-50 http://dx.doi.org/10.4311/2011ES0246

Deininger M., Fohlmeister J., Scholz D. \& Mangini A., 2012 - Isotope disequilibrium effects: The influence of evaporation and ventilation effects on the carbon and oxygen isotope composition of speleothems - A model approach. Geochimica et Cosmochimica Acta, 96: $57-79$.

http://dx.doi.org/10.1016/j.gca.2012.08.013

Dreybrodt W., 1999 - Chemical kinetics, speleothem growth and climate. Boreas, 28: 347-356.

http://dx.doi.org/10.1080/030094899422073

Dreybrodt W., 2012 - Speleothem deposition. In: White W.B. \& Culver D.C. (Eds.), Encyclopedia of caves. Elsevier, p. 769-777.

http://dx.doi.org/10.1016/B978-0-12-383832-2.00112-2

Fairchild I.J. \& Baker A., 2012 - Speleothem science: From process to past environments. John Wiley \& Sons, Chichester, $416 \mathrm{p}$. http://dx.doi.org/10.1002/9781444361094

Fairchild I.J., Frisia S., Borsato A. \& Tooth A.F., 2007 - Speleothems. In: Nash D.J. \& McLaren S.J. (Eds.), Geochemical Sediments and Landscapes. Blackwell, Oxford, p. 200-245. http://dx.doi.org/10.1002/9780470712917.ch7

Fairchild I.J., Smith C.L., Baker A., Fuller L., Spötl C., Mattey D. \& McDermott F., 2006 - Modification and preservation of environmental signals in speleothems. Earth and Planetary Science Letters, 75: 105-153. http://dx.doi.org/10.1016/j.earscirev.2005.08.003

Fernández P.L., Gutierrez I., Quindós L.S., Soto J. \& Villar E., 1986 - Natural ventilation of the paintings room in the Altamira cave. Nature, 321: 586-588. http://dx.doi.org/10.1038/321586a0

Fernandez-Cortes A., Sanchez-Moral S., Cuevza S., Cañaveras J.C. \& Abella R., 2009 - Annual and transient signatures of gas exchange and transport in the Castañar de Ibor cave (Spain). International Journal of Speleology, 38: 153-162 http://dx.doi.org/10.5038/1827-806X.38.2.6

De Freitas C.R., Littlbjohn R.N., Clarkson T.S. \& Kristament I.S., 1982 - Cave climate: Assessment of airflow and ventilation. Journal of Climatology, 2: 383-397. http://dx.doi.org/10.1002/joc.3370020408

Frisia S., Fairchild I.J., Fohlmeister J., Miorandi R., Spötl C. \& Borsato A., 2011 - Carbon mass-balance modelling and carbon isotope exchange processes in dynamic caves. Geochimica et Cosmochimica Acta, 75: 380-400.

http://dx.doi.org/10.1016/j.gca.2010.10.021

Gabitov R.I. \& Watson E.B., 2006 - Partitioning of strontium between calcite and fluid. Geochemistry, Geophysics, Geosystems, 7: 1-12.

http://dx.doi.org/10.1029/2005GC001216

Geiger R., 1961 - Das Klima der bodennahen Luftschicht: ein Lehrbuch der Mikroklimatologie. Springer, Braunschweig.

Genty D., 2008 - Palaeoclimate research in Villars Cave (Dordogne, SW-France). International Journal of Speleology, 37: 173-191. http://dx.doi.org/10.5038/1827-806X.37.3.3

Genty D. \& Deflandre G., 1998 - Drip flow variations under a stalactite of the Père Noël cave (Belgium): Evidence of seasonal variations and air pressure constraints. Journal of Hydrology, 211: 208-232. http://dx.doi.org/10.1016/S0022-1694(98)00235-2 
Giusti E. V., 1978 - Hydrogeology of the karst of Puerto Rico. Geological Survey Professional Paper 1012, United States Government Printing Office, Washington, 65 p.

Gregorič A., Vaupotič J. \& Gabrovšek F., 2013 - Reasons for large fluctuation of radon and $\mathrm{CO}_{2}$ levels in a dead-end passage of a karst cave (Postojna Cave, Slovenia). Natural Hazards and Earth System Science, 13: 287-297.

http://dx.doi.org/10.5194/nhess-13-287-2013

Hoyos M., Soler V., Cañaveras J.C., Sánchez-Moral S. \& Sanz-Rubio E., 1998 - Microclimatic characterization of a karstic cave: human impact on microenvironmental parameters of a prehistoric rock art cave (Candamo Cave, northern Spain). Environmental Geology, 33: 231-242. http://dx.doi.org/10.1007/s002540050242

Jacobson M.Z., 2005 - Fundamentals of atmospheric modeling. Cambridge University Press, Cambridge, 813 p. http://dx.doi.org/10.1017/CBO9781139165389

James E.W., Banner J.L. \& Hardt B., 2015 - A global model for cave ventilation and seasonal bias in speleothem paleoclimate records. Geochemistry, Geophysics, Geosystems, 16: 1-12.

http://dx.doi.org/10.1002/2014GC005658

Kaufmann G. \& Dreybrodt W., 2004 - Stalagmite growth and palaeo-climate: an inverse approach. Earth and Planetary Science Letters, 224: 529-545.

http://dx.doi.org/10.1016/j.eps1.2004.05.020

Kim S.-T. \& O'Neil J.R., 1997 - Equilibrium and nonequilibrium oxygen isotope effects in synthetic carbonates. Geochimica et Cosmochimica Acta, 61: 3461-3475.

http://dx.doi.org/10.1016/S0016-7037(97)00169-5

Kowalczk A.J. \& Froelich P.N., 2010 - Cave air ventilation and $\mathrm{CO}_{2}$ outgassing by radon-222 modeling: How fast do caves breathe? Earth and Planetary Science Letters, 289: 209-219.

http://dx.doi.org/10.1016/j.eps1.2009.11.010

Kowalski A.S. \& Sánchez-Cañete E.P., 2010 - A new definition of the virtual temperature, valid for the atmosphere and the $\mathrm{CO}_{2}$-rich air of the vadose zone. Journal of Applied Meteorology and Climatology, 49: 1692-1695.

http://dx.doi.org/10.1175/2010JAMC2534.1

Lachniet M.S., 2004 - A 1500-year El Niño/Southern Oscillation and rainfall history for the Isthmus of Panama from speleothem calcite. Journal of Geophysical Research, 109 (D20): D20117.

http://dx.doi.org/10.1029/2004JD004694

Lachniet M.S., Burns S.J., Piperno D.R., Asmerom Y., Polyak V.J., Moy C.M. \& Christenson K., 2009 Climatic and environmental controls on speleothem oxygen-isotope values. Quaternary Science Reviews, 28: 412-432.

http://dx.doi.org/10.1016/j.quascirev.2008.10.021

Lindzen R.S., 1979 - Atmospheric Tides. Annual Review Earth Planetary Science, 7: 199-225.

http://dx.doi.org/10.1146/annurev.ea.07.050179.001215

Mattey D.P., Atkinson T.C., Barker J. A., Fisher R., Latin J.-P., Durell R. \& Ainsworth M., 2016 - Carbon dioxide, ground air and carbon cycling in Gibraltar karst. Geochimica et Cosmochimica Acta, 184: 88-113.

http://dx.doi.org/10.1016/j.gca.2016.01.041

Mattey D.P., Fairchild I.J., Atkinson T.C., Latin J.-P., Ainsworth M. \& Durell R., 2010 - Seasonal microclimate control of calcite fabrics, stable isotopes and trace elements in modern speleothem from St Michaels Cave, Gibraltar. Geological Society, London, Special Publications, 336: 323-344

http://dx.doi.org/10.1144/SP336.17
Meisner P., Riechelmann S., Jansen K., Richter D.K. \& Voigt S., $2010-\mathrm{CO}_{2}$ - Monitoring in drei Höhlen des Bergischen Landes-Aggertalhöhle, Kluterthöhle und Bismarckhöhle. Mitteilungen Verband deutscher Höhlen und Karstforschung, 56: 25-51.

Mickler P.J., Stern L. A. \& Banner J.L., 2006 - Large kinetic isotope effects in modern speleothems. Geological Society of America Bulletin, 118: 65-81 http://dx.doi.org/10.1130/B25698.1

Miller T.E., 2010 - Stream pirates of the Caribbean: Tanamá and Camuy Rivers in the northern karst of Puerto Rico. Espeleorevista Puerto Rico, 2: 8-13.

Monroe W.H., 1980 - Some tropical landforms of Puerto Rico. USGS Professional Paper 1159, United States Government Printing Office, Washington.

Neuweiler G., 2000 - The biology of bats. Oxford University Press, Oxford, 310 p.

Perrier F., Le Mouël J.-L., Poirier J.-P. \& Shnirman M.G., 2005 - Long-term climate change and surface versus underground temperature measurements in Paris. International Journal of Climatology, 25: 1619-1631. http://dx.doi.org/10.1002/joc. 1211

Pflitsch A. \& Piasecki J., 2003 - Detection of an airflow system in Niedzwiedzia (Bear) Cave, Kletno, Poland. Journal of Cave and Karst Studies, 65: 160-173.

Richon P., Perrier F., Pili E. \& Sabroux J.-C., 2009 Detectability and significance of $12 \mathrm{hr}$ barometric tide in radon-222 signal, dripwater flow rate, air temperature and carbon dioxide concentration in an underground tunnel. Geophysical Journal International, 176: 683-694.

http://dx.doi.org/10.1111/j.1365-246X.2008.04000.x

Ridley H.E., Prufer K.M., Walczak I.W. \& Studies K., 2015 - High-Resolution Monitoring of Yok Balum Cave, Belize: an investigation of seasonal ventilation regimes and the atmospheric and drip-flow response to a local earthquake. Journal of Cave and Karst Studies, 77: 183-199.

http://dx.doi.org/10.4311/2014ES0117

Riechelmann D.F.C., Schröder-Ritzrau A., Scholz D., Fohlmeister J., Spötl C., Richter D.K. \& Mangini A., 2011 - Monitoring Bunker Cave (NW Germany): A prerequisite to interpret geochemical proxy data of speleothems from this site. Journal of Hydrology, 409: 682-695.

http://dx.doi.org/10.1016/j.jhydrol.2011.08.068

Sánchez-Cañete E., Serrano-Ortiz P., Domingo F., \& Kowalski A., 2013 - Cave ventilation is influenced by variations in the $\mathrm{CO}_{2}$-dependent virtual temperature. International Journal of Speleology, 42: 1-8. http://dx.doi.org/10.5038/1827-806X.42.1.1

Spötl C., Fairchild I.J. \& Tooth A.F., 2005 - Cave air control on dripwater geochemistry, Obir Caves (Austria): Implications for speleothem deposition in dynamically ventilated caves. Geochimica et Cosmochimica Acta, 69: 2451-2468

http://dx.doi.org/10.1016/j.gca.2004.12.009

Tans P. \& Keeling R., 2014 - NOAA/ESRL http://www. esrl.noaa.gov/gmd/ccgg/trends/ [accessed: January 25, 2016].

Tarhule-Lips R.F.A. \& Ford D.C., 1998 - Condensation corrosion in caves on Cayman Brac and Mona Island. Journal of Cave and Karst Studies, 60: 84-95.

Vieten R., Winter A., Samson A.V.M., Cooper J., Wrapson L., Kambesis P.N., Lace M.J. \& Nieves M.A., 2016 Quantifying the impact of human visitation in two cave chambers on Mona Island (Puerto Rico): implications for archeological site conservation. Cave and Karst Science, 43: $79-85$. 
Vieten R., Winterhalder S., Winter A., Scholz D., Miller T., Spötl C. \& Schroeder-Ritzrau A., - Monitoring of Cueva Larga, Puerto Rico - a First Step to Decode Speleothem Climate Records. In White W., Herman E., Rutigliano M., Herman J., Vesper D., \& Engel S. (Eds.), Karst Groundwater Contamination and Public Health. Selected papers and abstracts of the symposium held January 27 through 30, 2016, San Juan, Puerto Rico. Karst Waters Institute Special Publication 19, Karst Waters Institute, Leesburg, Virginia, 74 p. (in press).

Wang Y.J., Cheng H., Edwards R.L., An Z.S., Wu J.Y., Shen C.C. \& Dorale J.A, 2001 - A high-resolution absolute-dated late Pleistocene Monsoon record from Hulu Cave, China. Science, 294: 2345-2348. http://dx.doi.org/10.1126/science. 1064618
Winter A., Miller T., Kushnir Y., Sinha A., Timmermann A., Jury M.R., Gallup C., Cheng H. \& Edwards R.L., 2011 - Evidence for 800 years of North Atlantic multidecadal variability from a Puerto Rican speleothem. Earth and Planetary Science Letters, 308: 23-28. http://dx.doi.org/10.1016/j.eps1.2011.05.028

Wong C.I., Banner J.L. \& Musgrove M., 2011 - Seasonal dripwater $\mathrm{Mg} / \mathrm{Ca}$ and $\mathrm{Sr} / \mathrm{Ca}$ variations driven by cave ventilation: Implications for and modeling of speleothem paleoclimate records. Geochimica et Cosmochimica Acta, 75: 3514-3529.

http://dx.doi.org/10.1016/j.gca.2011.03.025 